\title{
Pelayanan Penyaluran Bantuan Sosial Tunai (BST) di Kantor Pos Kecamatan Dumoga Utara
}

\author{
Dewi Rosanti 1), Yanti Aneta 2), Melizubaida Mahmud 3), Sri Indriyani S. Dai 4) \\ 1)Mahasiswa Fakultas Ekonomi, Universitas Negeri Gorontalo \\ 2),3),4)Dosen Fakultas Ekonomi, Universitas Negeri Gorontalo \\ dewirosanti678@gmail.com
}

\begin{abstract}
The Purpose of the present work is to investigate : 1 . the procedures of Cash cocial Assistance and 2. Factors affecting the distribution of the social assistance at the post office of Dumoga Utara District, Bolaang Mongondow Regency, In this qualitative discriptive research, all data were from observation, in-depth interviews and documents. The result showed that :1) the distribution procedures of the Directorate General of Poverty Handling No.18/6/SK/HK.02.02/4/2020. 2) There were several contributing factors to the distribution services of the social asistance, some factors were positively significant to maximum servies, while the others hinered the cash asistance programs. By that, Social service and the post office should take into consideration all factors that are crucial to cash social asistance distribution.
\end{abstract}

Keywords : Service, Distribution of Cash Social Asistance

\section{Pendahuluan}

Awal tahun 2020 masyarakat diseluruh dunia dihebohkan dengan pandemi virus Corona atau Covid-19 yang menyebar hampir keseluruh negara yang ada didunia ini. WHO semenjak Januari 2020 telah menyatakan dunia masuk ke dalam darurat global terkait virus ini. Virus yang pertama kali berkembang di Wuhan ini telah sampai di Indonesia pada awal Maret lalu. Diketahui bahwa pasien Covid-19 pertama di Indonesia ada 2 orang, yakni Ibu dan Anaknya yang tinggal di Daerah Depok, Jawa Barat. Hingga saat ini, kasus positif Covid-19 mencapai 474.455 kasus dengan 398.636 sembuh dan 15.393 meninggal. Khusus di Indonesia sendiri pemerintah sudah mengeluarkan status darurat bencana terhitung mulai tanggal 29 Februari 2020 hingga 29 Mei 2020 terkait pandemi virus ini dengan jumlah waktu 91 hari. Dalam mengatasi penyebaran Covid-19 ini, pemerintahtelah melakukan beberapa kebijakan, antara lain seperti menetapkan wabah virus Covid-19 ini sebagai bencana nasional melalui Keputusan Presiden Republik Indonesia Nomor 2 Tahun 2020 tentang Penetapan Bencana Non-Alam Penyebaran corona virus disease 2019 (Covid-19) sebagai bencana nasional. Pemerintah juga menerapkan pembatasan sosial berskala besar (PSBB) untuk daerah-daerah yang termasuk kedalam zona merah melalui peraturan mentri kesehatan (permenkes) Nomor 9 Tahun 2020 tentang pedoman PSBB. 
Setelah wabah COVID-19 dinyatakan sebagai bencana nasional dan pandemi, beberapa wilayah melakukan pembatasan wilayah berskala besar (PSBB) guna mencegah penyebaran yang lebih bayak. Hal ini menyebabkan dampak yang cukup signifikan terhadap kelangsungan hidup masyarakat, karena interaksi sosial masyarakat terbatasi yang akhirnya membuat aktivitas ekonomi terganggu, pekerjaan harian menjadi tidak bisa dilakukan, dan bayaknya gelombang PHK oleh perusahaan karena ketidakmampuan perusahaan mempertahankan karyawan dalam situasi pandemi. Belum lagi akibat penurunan penghasilan tersebut, angka kriminalitas bertambah sehingga pemerintah akhirnya memilih kebijakan untuk memberikan bantuan sosial sebagai bentuk tanggungjawab negara kepada masyarakat untuk mengantisipasi semua permasalahan sosial ekonomi terkait COVID-19. Khusus di Kecamatan Dumoga Utara, Kabupaten Bolaang Mongondow, Sulawesi Utara,bantuan-bantuan yang diterima selama masa pandemi yakni, Bantuan Langsung Tunai (BLT), Bantuan Sosial Tunai (BST), Bantuan Sosial (BanSos) dan Bantuan Modal yang diberikan kepada pelaku-pelaku UMKM yang terdampak Covid-19. Bantuan Sosial Tunai (BST) ini merupakan bantuan Non-Reguler yakni bantuan yang diberikan kepada masyarakat terdampak pandemi Covid19. Bantuan Sosial Tunai (BST) ini disalurkan setiap bulandiwilayah yang telah di tetapkan. Penyaluran bantuan ini berlangsung sejak bulan April 2020.
Pada tahun 2020, penyaluran Bantuan Sosial Tunai (BST) dilakukan secara dua gelombang. Gelombang pertama diberikan pada bulan April hingga bulan Juni 2020, dengan bantuan yang disalurkan sebesar Rp600.000,00 per bulan. Kemudian, dilakukan perpanjangan hingga Desember 2020. Pada gelombang kedua ini, bantuan disalurkan mulai bulan Juli hingga Desember 2020, dengan bantuan yang disalurkann sebesar Rp300.000,00 per bulan.

Di Kecamatan Dumoga Utara, Kabupaten Bolaang Mongondow khususnya, penyaluran Bantuan Sosial Tunai (BST) diselenggarakan oleh Kantor Pos Kecamatan Dumoga Utara, sebab seluruh Anggaran dana bantuan dari pemerintah masuk ke Kantor Pos.

Desa yang berada di wilayah Kecamatan Dumoga Utara ada 16 Desa meliputi; Desa Mopuya Selatan, Mopuya Utara, Mopuya Selatan 1, Mopuya Utara 1, Mopuya Selatan 2, Mopuya Utara 2, Mopugad Utara, Mopugad Selatan, Mopugad Utara 1, Mopugad Selatan 1, Mopugad Utara 2, Tumokang Baru, Tumokang Timur, Dondomon, Dondomon Utara, dan Dondomon Selatan.

Jumlah penerima disetiap desa yang ada di Kecamatan Dumoga Utara tidak sama. Pada pencairan Tahap 1 sampai Tahap 5 yakni dari Bulan April sampai Agustus jumlah penerima sebanyak 612 orang dan pada pencairan Tahap 6 sampai Tahap 8 yakni dari bulan September sampai November jumlah penerima Bantuan Sosial Tunai (BST) di Kecamatan Dumoga Utara 
mengalami pengurangan hingga saat ini jumlah penerima hanya 361 orang.

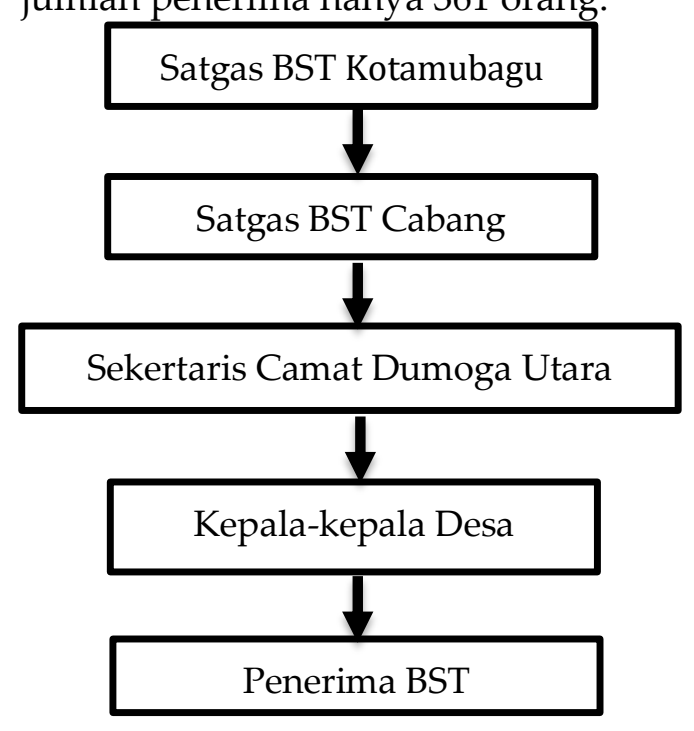

Gambar 1.1 Informasi Pencairan Dana BST di Kecamatan Dumoga Utara

Pada pencairan BST bulan ini yakni pada tanggal 11 November 2020 kemarin, dari seluruh penerima BST yang ada di Kecamatan Dumoga Utara masih ada 12 orang penerima BST yang belum mengambil uang BST tersebut. Sedangkan informasi pencairan sudah terlebih dahulu diberitahukan, namun masih ada saja masyarakat penerima yang belum juga mengambil Dana BST nya hingga saat ini. Kemudian sarana dan prasarana yang ada pada saat pelayanan penyaluran Bantuan Sosial Tunai (BST) berlangsungYang menjadi masalah terakhir yang muncul yakni pengawasan dari APIP yang belum terlaksana sejak awal pelayanan penyaluran BST ini berlangsung hingga saat ini.

\section{Tinjauan Pustaka}

\section{Kualitas Pelayanan}

Menurut Tjiptono (2015 : 51) konsep kualitas sering dianggap sebagai ukuran relative kebaikan sebuah produk barang atau jasa yang terdiri dari kualitas desain dan kualitas kesuaian. Selanjutnya, Foster (200: 188) dalam Zuchri (2014 : 16) dalam penelitian mutakhir dibidang pelayanan jasa, menyatakan bahwa tingkat kepuasan pelanggan atas pelayanan yang mereka terima dari karyawan bahwa gugus depan secara tidak langsung berakibat kepada naiknya tingkat kepercayaan pelanggan terhadap perusahaan.

Setyawati (2013 : 48) dalam Fitriah (2016:9) pelayanan adalah cara melayani (membantu menerus atau menyiapkan segala keprluan yang dibutuhkan seseorang). Kualitas layanan adalah pelayanan yang dapatmemberikan kepuasan kepada pelanggan dan tetap dalam batas memenuhi standar pelayanan yang dapat di pertanggung jawabkan serta harus terus menerus dilakukan. Harari (2000 : 188) dalam Zuchri (2014 : 16) melakukan analisis terhadap kualitas pelayanan dan menghasilkan kesimpulan bahwa buruknya pelayanan yang dilakukan sebuah organisasi justru lebih banyak disebabkan karena permasalahan yang terletak dimanajemen puncak.

Secara teroritis, tujuan pelayanan publik pada dasarnya adalah memuaskan masyarakat. Untuk mencapai kepuasan itu dituntut kualitas pelayanan prima yang tercemin dari (Muchlis $2015:$ 23): 1. Transparansi, 2. Akuntabilitas, 3. Kondisional, 4. Partisipatif , 5. Kesamaan Hak.

KEPMENPANNo.63/KEP/M.PA N/7/2003, pelayanan publik adalah segala kegiatan pelayanan yang 
dilaksanakan oleh penyelenggara pelayanan publik sebagai upaya pemenuhan kebutuhan penerima pelayanan maupun pelaksanaan ketentuan peraturan perundangundangan.

Dengan demikian, pelayanan publik adalah pemenuhan keinginan dan kebutuhan masyarakat oleh penyelenggara Negara. Negara didirikan oleh Publik (masyarakat) tentu saja dengan tujuan agar dapat meningkatkan kesejahteraan masyarakat. Pada hakikatnya Negara dalam hal ini pemerintah (Birokrat) haruslah dapat memenuhi kebutuhan masyarakat. Kebutuhan dalam hal ini bukanlah kebutuhan secara individual akan tetapi sebagai kebutuhan yang sesungguhnya diharapkan oleh masyarakat, misalnya kebutuhan akan kesehatan pendidikan. (Muchlis 2015 : 29)

\section{Program Bantuan Sosial Pemerintah di Indonesia}

Menurut Kementerian Sosial (2011), bantuan sosial adalah bantuan yang sifatnya sementara yang diberikan kepada masyarakat miskin, dengan maksud agar mereka dapat meningkatkan kehidupannya secara wajar. Program bantuan sosial merupakan salah satu komponen program jaminan sosial yang menjadi bentuk realisasi tanggung jawab pemerintah pusat atau pemerintah daerah yang sangat peduli terhadap kondisi masyarakat miskin dan terlantar di tingkat bawah. Program ini merupakan implementasi UndangUndang Dasar 1945 pasal 34 ayat 1 yang menyatakan bahwa fakir miskin dan anak-anak terlantar dipelihara oleh negara. Selain itu pada UndangUndang dasar 1945 pasal 34 ayat 2 menyebutkan bahwa negara mengembangkan sistem jaminan sosial bagi seluruh rakyat dan memberdayakan masyarakat yang lemah dan tidak mampu sesuai dengan martabat kemanusiaan. Kesejahteraan sosial adalah kondisi terpenuhinnya kebutuhan material, spiritual,dan sosial warga negara agar dapat hidup layak dan mampu mengembangkan diri, sehingga dapat melaksanakan fungsi sosialnya. Pasal 34 ayat (1) UndangUndang Dasar 1945 mengamanatkan kewajiban negara untuk memelihara fakir miskin dan anak terlantar. Bagi fakir miskin dan anak terlantar seperti yang dimaksud dalam Undang-Undang Dasar Negara 1945, Pemerintah Pusat dan Pemerintah Daerah, memberikan rehabilitasi, sosial, jaminan sosial, pemberdayaan sosial, dan perlindungan sosial sebagai perwujudan pelaksanaan kewajiban negara dalam menjamin terpenuhinya hakatas kebutuhan dasar warga negara yang miskin dan tidak mampu.

Untuk menangani Covid-19,

ditetapkan Peraturan Menteri

Keuangan Nomor 43/PMK.05/2020 tentang Mekanisme Pelaksanaan Anggaran Belanja Negara dalam Penanganan Pademi Corona Virus Disease 2019 (PMK 43/2020). Pertimbangan ditetapkanya PMK 43/2020 yaitu bahwa berdasarkan ketentuan Pasal 2 ayat (1) huruf d dan huruf k Peraturan Pemerintah Pengganti Undang-Undang Nomor 1 Tahun 2020 tentang Kebijakan 
Keuangan Negara dan Stabilitas Sistem Keuangan untuk Penanganan Pandemi Corona Virus Disease 2019 (Covid-19) dan/atau dalam rangka menghadapi Ancaman yang Membahayakan Perekonoman Nasional dan/atau Stablitas Sistem Keuangan, pemerintah berwenang untuk melakukan tindakan yang berakibat pengeluaran atas beban Anggaran Pendapatan dan Belanja Negara, yang anggaran untuk membiayai penggeluaran tersebut belum tersedia atau tidak cukup tersedia, serta menentukan proses dan metode pengadaan barang/jasa serta melakukan penyederhanaan mekanisme dan simplifiksai dokumen dibidang keuangan negara.

Bantuan Sosial Tunai (BST) merupakan bantuan Non-Reguler yakni bantuan yang diberikan kepada masyarakat terdampak pandemic Covid-19 dan bantuan ini merupakan bantuan pemerintah yang bersumber dari Kementerian sosial (Kemensos) yang akan disalurkan kepada masyarakat berdasarkan Data Terpadu Kesejahteraan Sosial (DTKS). Bantuan Sosial Tunai (BST) ini disalurkan setiap bulan ke-33 wilayah yang ada di Indonesia. Penyaluran bantuan ini berlangsung sejak bulan April 2020.

Bantuan Sosial Tunai (BST) diputuskan dalam Keputusan Menteri Sosial Republik Indonesia Nomor 54/HUK/2020 Tentang Pelaksanaan Bantuan Sembako dan Bantuan Sosial Tunai dalam Penanganan Dampak Corona Virus Disease 2019 (Covid-19).

Pelaksana penyaluran belanja Bantuan Sosial (Bansos) pada Kementerian Negara/Lembaga dalam bentuk uang dapat dilakukan melalui Bank/Pos penyaluran kepada penerima Bantuan Sosial (Bansos). Dalam hal ini, Petunjuk Teknis Pelaksanaanya ditetapkan dalam Keputusan Direktur Jenderal Pajak Penanganan Fakir Miskin No.18/6/SK/HK.02.02/4/2020 TENTANG Petunjuk Teknis Penyaluran Bantuan Sosial Tunai dalam Penanganan Dampak Corona Virus Disease (Covid-19).

Berdasarkan

Keputusan

Direktur Jenderal Penanganan Fakir Miskin No. 18/6/SK/HK.02.02/4/2020, KPM Bantuan Sosial Tunai (BST) diutamakan bagi keluaga yang tercantum dalam data terpadu kesejahteraan sosial yang bukan terdaftar sebagai penerima program keluarga harapan, program sembako.

Pemerintah

Daerah

Kabupaen/Kota dapat mengusulkan KPM Bantuan Sosial Tunai Baru melalui sistem informasi kesejahteraan sosialnext generation (SIKS-NG). Persyaratan bagi KPM baru yang diusulkan harus merupakan keluarga miskin yang tidak meneria program keluarga harapan, program sembako. Untuk data KPM Bantuan Sosial Tunai baru yang diusulkan pemerintah daerah Kabupaten/Kota harus dilengkapi Nomor Induk Kependudukan (NIK)/Nomor Kartu Keluarga (KK) dan nomor telepon yang dapat dihubungi.

\section{Metode Penelitian \\ Pendekatan, Metode dan Prosedur Penelitian}

Pendekatan yang digunakan pada penelitian ini adalah pendekatan penelitian kualitatif dengan metode 
deskriptif kualitatif. Menurut Sugiyono (2017:9) metode penelitian kualitatif adalah metode penelitian yang berlandaskan pada filsafat postpositivisme atau enterpretif, digunakan untuk meneliti pada kondisi objek yang ilmiah, dimana peneliti adalah sebagai instrument kunci, teknik pengumpulan data dilakukan secara trianggulasi (gabungan observasi, wawancara, dokumentasi), data yang diperoleh cenderung data kualitatif, analisis data bersifat induktif/kualitatif, dan hasil penelitian bersifat untuk memahami makna, memahami keunikan, mengkonstruksi fenomena dan menemukan hipotesis.

Penelitian ini dimaksudkan untuk memberi gambaran secara jelas tentang Pelayanan Penyaluran Bantuan Sosial Tunai (BST) di Kantor Pos di Kecamatan Dumoga Utara Kabupaten Bolaang Mongondow. Waktu penelitian yang dibutuhkan peneliti dari observasi awal dilaksanakan pada minggu ketiga dan keempat November 2020. Selanjutnya, penelitian lapangan yang dilakukan pada minggu ketiga bulan Januari sampai minggu kedua bulan Maret 2021.

Kehadiran peneliti selain sebagai pengumpul data juga bertindak sebagai instrument penelitian. Peneliti sebagai key instrument berusaha untuk mengungkap bagaimana Evaluasi Pelayanan Penyaluran Dana Bantuan Sosial (BST) di Kecamatan Dumoga Utara, Kabupaten Bolaang Mongondow. Urgensi peran peneliti nampak dalam proses penelitian mulai dari awal sampai akhir penelitian yang meliputi: menentukan informan, wawancara dengan informan, meneliti dokumen, membuat rekaman arsip, membuat reduksi data dan menyajikan data, menganilisis data dan menginterprestasi hasil penelitian.

Bagian lain yang tidak terpisahkan dalam proses penelitian adalah observasi, dimana peran peneliti dituntut untuk melakukan pengamatan terhadap aktivitas yang terjadi dalam birokrasi, seperti hubungan antara staf dengan staf, antara pimpinan dengan staf. Dalam observasi, peneliti akan melakukan pengamatan langsung dengan keluarga penerima Bantuan Sosial Tunai (BST).

Sumber data dalam penelitian ini adalah data primer dan data sekunder. Teknik pengambilan sampel yang digunakan adalah purposive, yakni sampel yang diambil dengan berdasarkan pertimbangan subyektif peneliti, dimana persyaratan yang dibuat sebagai kriteria harus dipenuhi sebagai sampel.

Dalam pengecekan tentang kebenaran hasil penelitian, maka peneliti mengambil beberapa informan diantaranya:

Tabel 3.2Narasumber

\begin{tabular}{|r|c|c|}
\hline No & Nama & $\begin{array}{c}\text { Jabatan } \\
\text { (Pekerjaan) }\end{array}$ \\
\hline 1. & $\begin{array}{c}\text { Rajab } \\
\text { Birahim }\end{array}$ & $\begin{array}{c}\text { Kepala Kantor } \\
\text { Pos Kecamatan } \\
\text { Dumoga Utara }\end{array}$ \\
\hline 2. & $\begin{array}{c}\text { Frengki } \\
\text { Talipi }\end{array}$ & $\begin{array}{c}\text { Pegawai Kantor } \\
\text { Pos }\end{array}$ \\
\hline 3. & $\begin{array}{c}\text { Hery } \\
\text { Setiawan }\end{array}$ & $\begin{array}{c}\text { Kepala Desa } \\
\text { Mopugad Utara }\end{array}$ \\
\hline 4. & $\begin{array}{c}\text { I Made } \\
\text { Merta }\end{array}$ & $\begin{array}{c}\text { Kepala Desa } \\
\text { Mopugad Selatan }\end{array}$ \\
\hline
\end{tabular}




\begin{tabular}{|r|c|c|}
\hline 5. & $\begin{array}{c}\text { Wanti } \\
\text { Toligaga }\end{array}$ & Sekertaris Camat \\
\hline 6. & $\begin{array}{c}\text { Miratun } \\
\text { Miswah }\end{array}$ & $\begin{array}{c}\text { Pendamping } \\
\text { TSKS }\end{array}$ \\
\hline 7. & $\begin{array}{c}\text { Siti Fatma } \\
\text { Mamonto }\end{array}$ & Penerima BST \\
\hline 8. & Saimin & Penerima BST \\
\hline 9. & Winarti & Penerima BST \\
\hline 10. & $\begin{array}{c}\text { Ahmad } \\
\text { Junaedi }\end{array}$ & Penerima BST \\
\hline 11. & $\begin{array}{c}\text { Rolin } \\
\text { Husain }\end{array}$ & Penerima BST \\
\hline 12. & Hariani & Penerima BST \\
\hline 13. & Pariiyem & Penerima BST \\
\hline 14. & Nasida & Penerima BST \\
\hline 15. & Giati & Penerima BST \\
\hline 16. & Misliatun & Penerima BST \\
\hline 17. & $\begin{array}{c}\text { Lilik } \\
\text { Apriyanti }\end{array}$ & Penerima BST \\
\hline 18. & Putu Sutini & Penerima BST \\
\hline
\end{tabular}

\section{Teknik Pengumpulan Data}

Teknik pengumpulan data yang digunakan dalam penelitian ini yaitu melalui observasi (alam hal ini peneliti tidak ikut serta dalam kegiatan penyaluran bantuan sosial tunai (BST) di Kantor Pos di Kecamatan Dumoga Utara Kabupaten Bolaang Mongondow, melainkan hanya mengamati), wawancara mendalam (interview), dan dokumentasi.

\section{Teknik Analisa Data}

Teknik analisa data dalam penelitian ini dilakukan melalui tahapan reduksi data, penyajian data, dan penarikan kesimpulan atau verifikasi. Tahapan ini merupakan kegiatan yang menjalin antara sebelum, selama dan sesudah pengumpulan data dalam bentuk yang sejajar.

\section{Hasil Penelitian}

Prosedur Pelayanan Penyaluran Bantuan Sosial Tunai (BST) di Kantor Pos Kecamatan Dumoga Utara Kabupaten Bolaang Mongondow

\section{a. Penetapan Penerima Bantuan}

\section{Sosial Tunai (BST)}

Berdasarkan Keputusan DirJen Penanganan Fakir Miskin No. 18/6/SK/HK.02.02/4/2020 tentang Petunjuk Juknis Penyaluran Bantuan Sosial Tunai dalam Penanganan Dampak Corona Virus Disease 2019,berdasarkan penetapan KPM maka diperoleh hasil hasil wawancara dengan Pendamping TSKS (Tenaga Kesejahteraan Sosial) Kecamatan Dumoga Utara sebagai berikut: “BST ini yang menetapkan nama-nama penerimanya dari Dinas Sosial. Nama-nama penerima BST ini langsung ada. Meskipun alur sebenarnya harus di evaluasi dari Desa dulu dengan kriteria RTM (Rumah Tangga Miskin). Namun untuk di Kecamatan Dumoga Utara, nama-nama penerima BST langsung ditetapkan dari Dinas Sosial". (MM. 16 Maret 2021)

Senada dengan pernyataan yang dikatakan oleh Sekertaris Camat Dumoga Utara perihal penetapan BST di Kecamatan Dumoga Utara yaitu: "Penerima BST langsung ditetapkan dari pusat melalui data Kesejahteraan Sosial yang ada. Kemudian nama-nama tersebut akan di berikan ke Kantor Pos dan ke Kantor Camat. Dan nama-nama penerima tersebut akan kami sampaikan ke setiap kepala desa yang ada dilingkungan Dumoga Utara ini." (WT. 16 Maret 2021)

Setelah itu, peneliti melakukan wawancara langsung dengan kepala desa Mopugad Utara untuk 
memperjelas fakta yang sudah di dapatkan dari pegawai kantor camat. Berikut ini hasil wawancara yang diperoleh: "untuk penerima BST ditentukan langsung oleh Dinas Sosial."(HS.06 Februari 2021)

Begitupun hasil wawancara yang diperoleh pada saat melakukan wawancara dengan Kepala Desa Mopugad Selatan yaitu: "Penetapan penerima BST langsung ditetapkan oleh Dinas Sosial bukan dari Desa."(IMM.06 Februari 2021)

Berdasarkan hasil wawancara diatas, dapat disimpulkan bahwa penetapan penerima Bantuan Sosial Tunai (BST) ditetapkan langsung oleh Dinas Sosial Kabupaten. Kemudian nama-nama penerima akan di bagikan ke kantor pos dan kantor camat untuk disampaikan ke setiap kepala Desa yang ada dilingkungan Kecamatan Dumoga Utara.

\section{b. Penggantian Penerima Bantuan Sosial Tunai (BST)}

Karena dalam penetapan penerima BST data yang digunakan adalah data dari Kesejahteraan Sosial, maka ada nama penerima yang sudah pindah domisili atau meninggal dunia. Dengan demikian, setiap kepala Desa akan melakukan pengajuan nama penerima BST pengganti. Berikut merupakan hasil wawancara yang dilakukan peneliti dengan pegawai sekertaris camat terkait dengan penggantian penerima BST: "untuk penggantian nama penerima BST, dimulai dari Desa. Sebab Kepala Desa yang lebih tahu, paham, dan mengenal masyarakatnya yang dianggap layak menerima bantuan. Kemudian daftar penerima baru di musyawarahkan di Desa. Nama-nama ini diajukan ke Dinas Sosial melalui Pendamping TSKS. Kemudian di proses dan menunggu jadwal penerimaan BST"(WT.16 Maret 2021)

Senada dengan pernyataan yang disampaikan oleh Pendamping TSKS (Tenaga Kesejahteraan) Kecamatan Dumoga Utara, yaitu: "kalau pengganti penerima BST barulah melalui Desa. Desa yang mengusulkan nama-namanya, kemudian diajukan ke Kantor Camat setelah dari kantor camat, saya dan rekan saya yang akan langsung membawa berkas pengajuan tersebut ke Dinas Sosial untuk di proses. Jika daftar penerima baru yang kami ajukan disetujui, maka pihak Dinas Sosial akan menghubungi kami dan kami akan sampaikan kekantor camat untuk diteruskan ke setiap kepala desa yang ada dilingkungan Kecamatan Dumoga Utara"(MM. 16 Maret 2021)

Namun dalam pengajuan pengganti atau pengusulan penerima BST yang baru ini syarat yang harus dipenuhi yakni calon penerima baru termasuk Rumah Tangga Miskin (RTM) dan bukan termasuk KPM program keluarga Harapan dan program sembako serta melampirkan No. NIK dan nomor KK calon penerima Baru. Berikut hasil wawancara dengan kepala Desa Mopugad Utara yaitu: "Ada satu warga saya yang menjadi peneirma BTS, namun telah pindah Domisili di Sulawesi Tengah. Dan untuk melakukan pengajuan penerima baru, banyak syarat yang harus dipenuhi dan dilampirkan diberkasnya. Jadi agak sedikit rumit. Meskipun demikian kami berusaha melakukan pengajuan penggatian penerima BST dan telah di setujui."(HS.06 Februari 2021) 
Begitu juga yang diperoleh peneliti saat melakukan wawancara dengan Kepala Desa Mopugad Selatan yaitu: "ada dua orang warga saya yang dialihkan ke bantuan lain. Dan saya melakukan pengajuan pengganti. Dengan melengkapi berkas dan melampirkan persyaratn yang diminta seperti Nomor Induk Kependudukan (NIK)/nomor Kartu Keluarga (KK). Kemudian saya antar berkasnya ke Kantor camat. Nanti jika disetujui Ibu Sekcam akan menghubungi saya dengan info jadwal penyalurannya juga." (IMM.06 Februari 2021)

Setiap permasalahan pasti ada solusinya. Karena data yang ada di Kesejahteraan Sosial merupakan data lama jadi ada beberapa penerima yang ternyata sudah pindah domisili, dipindah ke bantuan lain atau sudah meninggal dunia. Maka Kepala Desa dapat mengajukan penggatian Penerima Baru dengan menlampirkan Nomor Induk Kependudukan (NIK)/nomor Kartu Keluarga (KK) sesuai KepDirJen Penganggulangan Fakir Miskin No. 18/6/SK/HK.02.02/4/2020 tentang Petunjuk Juknis Penyaluran Bantuan Sosial Tunai dalam Penanganan Dampak Corona Virus Disease 2019.

Dalam proses pengajuan calon penerima baru yang diajukan oleh pemerintah Desa, yakni calon penerima baru merupakan keluarga Rumah Tangga Miskin (RTM) dan bukan merupakan penerima $\mathrm{PKH}$ dan program sembako.

\section{c. Proses Pelayanan Penyaluran Bantuan Sosial Tunai (BST)}

Jadwal penyaluran BST tidak tetap disetiap bulan berjalan. Sebab yang menentukan Tanggal penyaluran BST adalah pihak PT Posatau Kantor Pos Pusat (Kantor Pos Kotamobagu). Sebagaimana pernyataan yang disampaikan oleh Kepala Pos Cabang Mopuya yang menjadi tenaga Pos Penyalur Bantuan Sosial Tuni (BST) di Wilayah Kecamatan Dumoga Utara sebagai berikut: "Yang menetapkan tanggal penyaluran BST adalah Kantor Pos Pusat. Dari dinas sosial memberikan informasi kepada PT Pos atau Pos Pusat kemudian PT Pos membuat jadwal penyaluran setelah itu diinfokan ke Dinas Sosial dan ke Kantor Pos Cabang jadwal penyalurannya."(RB.02 Februari 2021).

Setelah jawal penyaluran sudah disampaikan ke dinas sosial dan ke kantor pos cabang, maka jadwal penyaluran akan disampaikan ke Kecamatan. Seperti yang di utarakan oleh Kepala Kantor Pos Cabang Mopuya yaitu: "setelah Pos cabang menerima jadwal penyaluran, kami akan menyampaikan jadwal penyalurannya ke ibu Sekcam. Nanti beliau yang meneruskan ke kepala-kepala Desa yangada di kecamatan Dumoga utara. Begitu pula yang dilakukan oleh Dinas Sosial. Setelah mendapatkan jadwal penyaluran dari PT pos, pihak dinas Sosial akan menyampaikan jadwal penyalurannya langsung ke kepala-kepala Desa."(RB. 02 Februari 2021).

$$
\text { Senada dengan yang }
$$

disampaikan oleh Sekertaris Camat tentang penyampaian jadwal penyaluran BST di Kecamatan Dumoga Utara, yaitu: "kami disini hanya menerima laporan dari pendamping TKSK (Tenaga Kesejahteraan) dan jadwal penyalurannya. Biasanya Pak Pos datang di kantor camat untuk memberikan jadwal penyaluran 
dibulan tersebut. Kemudian saya yang langsung menginfokan di grup kepala Desa jadwal penyalurannya. Nanti kepala Desa yang langsung menyebarkan jadwal penyaluran ke masyarakatnya yang menerima BST."(WT.16 Maret 2021)

Begitupun hasil wawancara yang peneliti peroleh dari wawancara dengan Kepala Desa Mopugad Selatan, yaitu: "Dinas sosial menyampaikan tanggal penyaluran BST di grup whatsapp. Kemudian saya memberitahukan kepada setiap Kepala Dusun yang ada untuk disampaikan ke setiap Penerima tanggal dan tempat penyaluran BST."(IMM.06 Februari 2021).

Jika Kepala Desa Mopugad Selatan mendapatkan informasi dari Dinas Sosial, lain hal nya dengan Kepala Desa Mopugad Utara yang mendapatkan Informasi dari Kantor Camat. Beginilah penjelasannya: "informasinya dari Kantor Pos Cabang Mopuya kemudian di beritahukan ke Kecamatan. Dari kecamatan diinfokan ke kepala-kepala Desa kemudian dari kepala desa diinfokan ke kepala-kepala dusun setelah itu baru informasinya sampai ke penerima." (HS.06 Februari 2021).

Meskipun kedua kepala desa ini berbeda jawaban, namun pernyataan keduanya sama seperti yang diungkapkan oleh Kepala Kantor Pos Cabang Mopuya tentang informasi jadwal penyaluran BST yang ada di Kecamatan Dumoga Utara. Ketika peneliti menggali lebih dalam tentang jadwal penyaluran ini, yakni mengapa tidak dari tenaga penyalur (Kantor Pos Cabang) yang langsung menginfokan jadwal penyaluran ke penerima yang ada, inilah pernyataan yang disampaikan oleh Kepala Kantor Pos: “ jadwal penyaluran dari PT Pos ke Kantor Pos Cabang mendadak. $\mathrm{H}-4$ atau $\mathrm{H}-3$ jadwal penyaluran baru informasi ini disampaikan ke kami. Sebab inilah kami dari pihak kantor pos tidak bisa menginformasikan jadwal penyaluranya langsung ke penerima BST. Mengingat waktu yang kami miliki dan jumlah penerima yang banyak. Juga mengingat adanya pandemic covid-19 ini jadi kami lebih memilih menyampaikannya lewat kecamatan." (RB. 02 Februari 2021)

Setelah melihat pernyataan dari kepala kantor pos cabang mopuya, peneliti mencoba menanyakan hal yang sama ke Sekertaris Camat Dumoga Utara, berikut hasil wawancaranya: "biasanya $H-4$ atau H-3 sebelum jadwal penyaluran baru saya dapat infonya." (WT.16 Maret 2021)

Dari hasil wawancara diatas dapat disimpulkan bahwa karena jadwal penyaluran yang tidak tetap disetiap bulan berjalan, maka dibutuhkan kerja sama antara Dinas Sosial, Kantor Pos Cabang, Pegawai Kecamatan, dan Perangkat Desa agar informasi jadwal penyaluran sampai ke penerima. Dan mengingat pula pandemic Covid-19 yang terjadi maka mengharuskan semua orang untuk tidak bertemu dengan orang banyak.

\section{Penyaluran Bantuan Sosial Tunai (BST)}

Berdasarkan Keputusan Direktur Jendral Penanganan Fakir Miskin tentang petunjuk teknis penyaluran Bantuan Sosial Tunai (BST) dalam penanganan dampak Corona Virus Disease 2019 (Covid-19), tentang penyaluran Bantuan Sosial Tunai (BST), dimana penyaluran BST dilakukan 
secara langsung dengan memperhatikan protokol kesehatan. Berikut adalah hasil wawancara yang diperoleh pada saat melakukan wawancara dengan Kepala Kantor Pos Cabang, yaitu: "dalam memberikan pelayanan penyaluran BST, kami tetap memperhatikan protocol kesehatan tentunnya. Dengan mewajibkan para penerima datang sesuai jam yang telah ditetapkan agar mereka tidak berkerumun untuk mengantri." ((RB. 02 Februari 2021)

Senada dengan pernyataan yang diutarakan oleh pegawai kantor pos yang bertugas menjaga loket pembayaran, sebagai berikut: "ketika saya menjaga loket, apabila ada penerima BST yang datang untung mengambil dana bantuannya maka mereka juga diwajibkan memakai masker dan mencuci tangan sebelum masuk. Dan duduk dengan berjarak-jarak." (FT.02 Februari 2021)

Pematuhan terhadap peraturan untuk tetap menerapkan protocol kesehatan dalam memberikan pelayanan penyaluran BST ini telah dilakukan oleh kantor pos. Mulai dari mencuci tangan, menggunakan Masker dan menjaga jarak dalam mengantri. Pada saat pelayanan penyaluran berlangsung, terdapat prosedur yang harus dijalankan oleh pihak penyalur, dalam hal ini pihak kantor pos. Berikut hasil wawancara yang diperoleh peneliti dengan Kepala Kantor Pos Cabang Mopuya: "Prosedur wajib yang harus kami jalankan yakni membayarkan seluruh dana bantuan yang ada keseluruh penerima. Namun jika misalnya penerima BST adalah kepala keluarga, dan penerima sedang tidak berada ditempat (Contohnya sedang keluar kota) maka kami bisa memberikan dana BST tersebut kepada nama selain penerima yang ada didalam KK (Kartu Keluarga) Penerima BST tersebut. Bisa Istri atau Anaknya. Juga kami wajib melakukan panyaluran BST sampai batas waktu yang ditentukan oleh PT Pos."(RB.02 Februari 2021)

Ada dua hal wajib yang harus dijalankan oleh pihak Kantro Pos yakni dana Bantuan Sosial harus dibayarkan secara keseluruhan dan pihak kantor pos wajib membayarkan dana Bantuan sampai batas waktu yang ditentukan. Pengambilan dana BST dapat diwakilkan dengan syarat yang mengambil dana BST dapat menunjukkan namanya di KK penerima BST yang diwakilkannya. Dengan demikian proses penyaluran dana BST bisa dilakukan. Namun, jika pada saat pelayanan penyaluran berlangsung penerima tidak datang dan tidak diwakilkan, maka dana BST dapat diambil sampai batas pembayaran BST. Berikut hasil wawancara dengan Kepala Kantor Pos Cabang mengenai kebijakan yang diberikan kepada penerima BST yang tidak datang dan tdiak di wakilkan saat pelayanan penyaluran berlangsung, yaitu: "Apabila pada saat penyaluran BST penerima tidak datang ditempat penyaluran yakni dikantor Desa Mopuya Utara, maka kami akan melakukan penyaluran di Kantor Pos. Kemudian apabila jadwal penyaluran untuk 3 kecamatan sudah selesai, hari keempat atau kelima setelah penyaluran dilakukan kami akan mengunjungi rumah penerima. Pertama-tama kami menghubungi Kepala Desa untuk menanyakan dimana rumah penerima. Kemudian kami langsung mencari rumah penerima dan melakukan 
penyaluran BST langsung ditempat. Apabila penerima nya tidak ada dirumah maka kami akan kembali ke rumah Kepala Desa untuk memberitahukan bahwa penerima atas nama ini tidak datang pada saat penyaluran BST kemarin dan kami sudah mengunjungi rumahnya tapi tidak ada orang. Kadang Kepala Desa mengatakan bahwa penerima tersebut sudah pindah keluar kota atau penerima tersebut ada dikebun dan sudah lama tidak pulang. Setelah itu kami memberitahu Kepala Desa bahwa batas penyaluran BST sampai tanggal sekian."(RB.02 Februari 2021)

Demikian pula yang penyataan dari pegawai kantor pos yang bertugas menjaga loket pada saat pelayanan penyaluran BST berlangsung, yaitu: “ kami berikan dulu kesempatan 3 hari untuk mengambil dana BSTnya di kantor pos. karena kami melayani 3 kecamatan dalam melakukan pelayanan penyaluran BST ini, maka jika kemarin pelayanan penyaluran BST untuk Dumoga Utara, dan hari ini jadwal penyaluran untuk Dumoga Barat maka sisa penerima wilayah Dumoga Utara yang belum mengambil dana BST nya kemarin, dapat mengambil dana BSTnya hari ini di kantor Pos. jadi disamping saya jaga loket, saya juga melayani penyaluran BST. Setelah 3 kecamatan selesai dilakukan penyaluran, kita lakuka kunjugan kerumahrumah penerima BST yang belum mengambil dana BST nya. Dan kami lakukan penyaluran secara langsung ditempat, karena Verifikasinya dilakukan secara online jadi kami bisa melakukannya dimana saja."(FT.02 Februari 2021)

Dapat disimpulkan bahwa apabila pada saat pencairan BST penerima tidak datang maka penerima bisa mengambilnya diKantor Pos
Cabang Mopuya. Waktu yang diberikan untuk pengambilan di Kantor Pos ada 3 hari selama Jadwal pencairan di 3 Kecamatan yang menjadi wilayah Kantor Cabang Mopuya. Setelah itu pegawai Kantor Pos akan turun langsung ke alamat penerima untuk melakukan penyaluran secara langsung ditempat. Dan jika penerima tidak ada dirumah, maka pengambilan dana BST dapat dilakukan dikantor Pos sampai batas waktu penyaluran yang ditentukan oleh PT Pos.

\section{Pembahasan}

Prosedur Pelayanan Penyaluran Bantuan Sosial Tunai (BST) di Kantor Pos Kecamatan Dumoga Utara Kabupaten Bolaang Mongondow

a. Penetapan Penerima Bantuan Sosial Tunai (BST)

Sebelum terjadinya proses pelayanan penyaluran ini, ada proses penetapan penerima BST.Berdasarkan Keputusan Direktur Jenderal Penanganan Fakir Miskin tentang Petunjuk Teknis Penyaluran Bantuan Sosial Tunai (BST) dalam Penanganan Dampak Corona Virus Disease 2019 (Covid-19), penetapan KPM (Keluarga Penerima Manfaat) BST diutamakan bagi keluarga yang tercantum dalam data terpadu kesejahteraan sosial yang bukan terdaftar sebagai penerima program keluarga harapan, program sembako. Dalam hal ini penetapan penerima BST langsung ditetapkan oleh Dinas Sosial.

Pada hasil wawancara diatas, semua pihak terkait menyatakan bahwa penetapan BST ditetapkan oleh Dinas Sosial, bukan merupakan usulan dari pemerintah Desa. Khusus dikecamatan 
Dumoga Utara, dalam hal ini penetapan penerima BST sudah mengikuti aturan juknis penyaluran BST yang telah diputuskan oleh Dirjen Penanganan Fakir Miskin.

Karena penetapan penerima BST ditetapkan oleh Dinas Sosial menggunakan data terpadu Kesejahteraan Sosial, ada beberapa penerima diKec. Dumoga Utara yang ternyata sudah meninggal dunia dan ada yang sudah pindah domisili. Akhirnya proses penyaluran menjadi terhambat. Dana BST yang masuk tidak dapat terealisaikan semua karena hal tersebut.

Tentu saja pihak kantor pos sebagai pos penyalur mencari keberadaan penerima yang tidak kunjung datang mengambil dan BST nya. Bagi penerima yang sudah meninggal dana BST dapat dibayarkan kepada anaknya dengan persyaratan tertentu. Dan jika pindah domisili, dana BST akan dikembalikan kepusat. Dan selanjutnya menjadi tugas pemerintah Desa untuk mengganti penerima yang tidak ada dengan penerima baru yang tergolong sebagai Rumah Tangga Miskin (RTM).

Dalam penetapa penerima BST di Kecamatan Dumoga Utara Kabupaten Bolaang Mongondow ini sudah sesuai dengan peraturan Keputusan Direktur Jenderal Fakir Miskin No. 18/6/SK/HK.02.02/4/2020 TENTANG Petunjuk Teknis Penyaluran Bantuan SosialTunai dalam Penanganan Dampak Corona Virus Disease (Covid-19) yakni, Penetapan calon penerima BST dilakukan untuk menetapkan wilayah dan jumlah calon
Keluarga Penerima Manfaat (KPM) menurut daerah provinsi, daerah Kabupaten/Kota, dan Kecamatan. Persyaratan KPM Bantuan Sosial Tunai (BST) diutamakan bagi keluarga yang tercantum dalam data terpadu kesejahteraan sosial yang bukan terdaftar sebagai penerima program keluarga harapan $(\mathrm{PKH})$ dan program sembako.

\section{b. Penggantian Penerima Bantuan Sosial Tunai (BST) \\ Di karenakan ada penerima} yang meninggal, dialihkan ke bantuan lain, dan pidah domisili maka harus diadakan penggantian penerima BST agar semua dana BST yang masuk ke rekening Pos Penyalur dapat terealisasikan. Pada penggantian penerima BST ini usulan nama-nama pengganti di buat oleh kepala Desa dengan melampirkan NIK dan No. KK. Kemudian diserahkan ke Kecamatan dan dari Kecamatan akan di ajukan ke Dinas Sosial untuk diproses lebih lanjut. Hal ini juga sesuai dengan keputusan Dirjen Penanganan Fakir Miskin tentang Petunjuk Teknis Penyaluran BST dalam Penanganan Dampak Corona Virus Disease 2019 (Covid-19). Jadi, dari hasil wawancara yang telah dituliskan diatas, dalam hal ini Kecamatan Dumoga Utara telah mengikuti peraturan yang telah ditetapkan dalam penggantian penerima BST.

Meskipun demikian syarat pada penggantian penerima BST atau pengusulan penerima BST yang baru yakni calon penerima baru termasuk Rumah Tangga Miskin (RTM) dan bukan termasuk KPM program 
keluarga Harapan dan program sembako, sejumlah Kepala Desa mengaku prosesnya penggantian tersebut cukup rumit. Karena tidak semua nama yang diajukan sebagai pengganti akan diterima oleh dinas sosial dan butuh waktu sedikit lama untuk menunggu persetujui dari dinas sosial. Jadi pemerintah desa harus berulang-ulang membuat usulan penggantian ini sampai berkasnya disetujui oleh Dinas Sosial. Meskipun demikian, pemerintah Desa tetap menunpuh jalan tersebut agar masyarakat yang belum menerima bantuan apapun dari pemerintah dan termasuk ke dalam RTM bisa mendapatkan bantuan juga.

Pada penggantian calon penerima BST di Kecamatan Dumoga Utara ini harus menjadi perhatian lagi bagi Dinas Sosial Kabupaten, sebab pada proses penggantian calon penerima BST tidak sesuai dengan peraturan Direktur Jenderal Penanganan Fakir Miskin No. 18/6/SK/HK.02.02/4/2020 TENTANG Petunjuk Teknis Penyaluran Bantuan SosialTunai dalam Penanganan Dampak Corona Virus Disease (Covid19) dimana pada penggantian calon penerima BST harus sesuai dengan persyaratan yang ada yakni bagi KPM baru yang diusulkan harus merupakan keluarga miskin yang tidak menerima program keluarga harapan dan program sembako.

\section{c. Proses Pelayanan Penyaluran Bantuan Sosial Tunai (BST)}

Jadwal penyaluran Tanggal penyaluran BST ini tidak tetap disetiap bulan berjalan. Hal ini karena yang menetapkan tanggal penyaluran BST adalah pihak PT Pos/Kantor Pos Pusat, dan biasanya informasi kapan penyaluran BST akan berlangsung diberitahukan oleh PT Pos ke setiap kantor pos cabang dan ke Dinas Sosial pada H-4 sebelum penyaluran dilaksanakan.

Setelah informasi jadwal penyaluran diterima oleh kantor pos cabang, kepala kantor pos akan datang ke kantor kecamatan untuk menginformasikan kepada Sekertaris camat tentang jadwal penyaluran. Dari sekertaris camat informasi tersebut akan diteruskan ke kepala Desa yang ada di lingkungan Kecamatan Dumoga Utara.

Selain itu, kepala Desa juga mendapatkan informasi jadwal penyaluran dari Dinas Sosial melalui grup whatsapp. Ada dua jalur penyampaian informasi jadwal pencairan, yakni dari sekertaris camat dan dari Dinas sosial.

Dari penyampaian informasi tentang jadwal penyaluran yang tidak langsung ini, akibat yang di timbulkan yakni kurangnya informasi yang didapatkan oleh penerima BST. Seperti halnya penyaluran BST tahap ke-11 yang tiba-tiba lokasi penyalurannya berbeda dengan lokasi penyaluran semula, akhirnya ada penerima yang kebingungan dengan lokasi penyaluran ini.

Mulai dari pegawai kantor pos, pegawai kecamatan haruslah menyampaikan informasi jadwal penyaluran dengan jelas sebab dalam informasi jadwal penyaluran itu selain ada waktu penyaluran juga ada lokasi penyaluran. Hal ini harus diperhatikan 
agar penerima tidak kebingungan dan mengaku kurang informasi dan hal inilah yang dapat menjadi penghambat penyaluran BST.

Ketika diteliti lebih dalam tentang penyampaian informasi tidak dilakukan secara langsung fakta yang ditemukan adalah, karena penyampain jadwal penyaluran dari PT Pos diterima pada $\mathrm{H}-4$ dan dengan melihat jumlah penerima BST yang banyak, maka waktu yang dibutuhkan untuk menginformasikan secara langsung itu tidak ada. Dengan alasan inilah mengapa dalam menyampaikan informasi jadwal penyaluran dibutuhkan beberapa instansi, seperti Dinas Sosial, Kecamata dan pemerintah Desa yang ada dilingkungan Kecamatan Dumoga Utara.

Pelayanan Penyaluran Bantuan Sosial Tunai (BST)

Sesuai Keputusan Direktur Jendral Penanganan Fakir Miskin tentang petunjuk teknis penyaluran Bantuan Sosial Tunai (BST) dalam penanganan dampak Corona Virus Disease 2019 (Covid-19), tentang penyaluran Bantuan Sosial Tunai (BST), dimana penyaluran BST dilakukan secara langsung dengan memperhatikan protokol kesehatan. Hal ini selalu diterapkan dalam setiap pelayanan penyaluran BST baik ditempat penyaluran dilaksanakan ataupun di kantor Pos. Mulai dari wajib menggunakan masker, menjaga jarak dan mencuci tangan. Hal ini pun tidak luput dari pengawasan Polsek Kecamatan Dumoga Utara. Disetiap pelaksanaan pelayanan penyaluran, ada anggota dari polsek yang mengawasi tentang penerapan $3 \mathrm{M}$ diatas.

Pada saat memberikan pelayanan dalam penyaluran BST, ada dua hal wajib dijalankan oleh pihak kantor pos, yakni membayarkan atau menyalurkan seluruh dana BST yang masuk dari Dinas Sosial keseluruh penerima yang ada di Kecamatan dan tetap melaksanakan pelayanan penyaluran BST sampai batas waktu yang ditentukan, minimal 2 minggu.

Apabila penerima tidak berada ditempat, pengambilan dana bisa diwakili oleh istri atau suami atau anak dari penerima BST yang namanya tertera di KK penerima BST tersebut. Dan jika penerima tidak datang di hari $\mathrm{H}$ penyaluran dikarenakan suatu hal dan tidak diwakilkan oleh siapapun, maka penerima bisa mengambil dana BST nya keesokan hari di Kantor Pos. Sebab penerima berhak mengambil dana BST nya dan pihak Kantor Pos wajib melakukan penyaluran BST ke penerima sampai batas waktu yang ditentukan oleh PT Pos.

Selain menunggu penerima yang mengambil dana BST nya dikantor pos pada 3 hari setelah penyaluran dilakukan, hari ke-4 atau ke- 5 pegawai kantor pos akan turun kerumah-rumah penerima untuk melakukan penyaluran BST secara langsung. Jika penerima tidak ada dirumah, maka pegawai pos akan menunggu sampai batas penyaluran yang telah ditetapkan dikantor pos. 


\section{Penutup}

\section{Kesimpulan}

Penulis dapat menarik kesimpulan bahwa Pelayanan Penyaluran Bantuan Sosial Tunai (BST) di Kantor Pos Kecamatan Dumoga Utara sebagai berikut:

1. Prosedur pelayanan penyaluran Bantuan Sosial Tunai (BST) di Kantor Pos kecamatan Dumoga Utara secara garis besar sudah sesuai dengan ketentuan, yang didukung oleh:

a. Proses Penetapan penerima BST di Kecamatan Dumoga Utara dilakukan oleh Dinas Sosial melalui Data Terpadu Kesejahteraan Sosial, hal ini pun sesuai dengan KEPDIRJEN Penanganan Fakir Miskin N0.18/6/SK/HK.02.02/4/2020.

b. Proses Penggantian penerima BST di Kecamatan Dumoga Utara belum sesuai dengan aturan KEPDIRJEN Penanganan Fakir Miskin

N0.18/6/SK/HK.02.02/4/2020.

c. Proses Pelayanan penyaluran yang dilakukan oleh Kantor Pos Cabang Mopuya dilakukan secara langsung dengan tetap memperhatikan protocol kesehatan dan prosedur wajib yang sudah diatur dalam KEPDIRJEN Fakir Miskin N0.18/6/SK/HK.02.02/4/2020.

2. Faktor yang mempengaruhi pelayanan penyaluran Bantuan Sosial Tunai (BST) di Kantor Pos kecamatan Dumoga Utara ini terbagi menjadi faktor pendukung dan faktor penghambat sebagai berikut: a. Faktor pendukung; dalam hal ini, yang menjadi faktor pendukung yakni Kualitas aparatur dan kompetensi aparatur. Dalam pemberian pelayanan, penerima BST menyatakan pelayanan sudah baik dan memuaskan.

b. Faktor penghambat; dalam hal ini, sarana prasarana dan pengawasan menjadi faktor penghambat dalam pelayanan penyaluran BST di Kantor Pos. sebab baik sarana prasana dan pengawasan masih lurang dan harus menjadi perhatian bagi Pos Penyalur

\section{Saran}

Sehubungan dengan hasil penelitian dan kesimpulan yang telah dikemukakan sebelumnya, maka peneliti dapat memberikan saran sebagai berikut:

1. Faktor pengambat dapat menjadi hal yang harus diperhatikan oleh Kantor Pos Cabang Mopuya, Pemerintah Desa, Pemerintah Kecamatan dan Dinas Sosial. Mulai dari Sarana Prasarana yang harus diperhatikan oleh kantor pos dan Pengawasan selama penyaluran BST berlangsung yang harus diperhatian oleh pemerintah Desa, pemerintah Kecamatan dan Dinas Sosial.

2. Bantuan yang diberikan pemerintah ini merupakan solusi yang diberikan kepada masyarakat saat pandemi Covid-19 ini menyerang Indonesia. Saran dari peneliti, pemerintah Desa dan kecamatan harus dapat mengurangi kemungkinan akan adanya hal-hal menyimpang yang 
muncul pada saat pengajuan nama calon pengganti penerima BST.

3. Untuk memperoleh bukti-bukti yang lebih lanjut tentang pelayanan penyaluran BST ini, calon peneliti lain agar dapat ikut serta dalam proses penyaluran BST yang dilaksanakan oleh Kantor Pos.

\section{Daftar Pustaka}

Abdussamad, Zuchri. 2014. Kompetensi Aparatur dalam Pelayanan Publik.CV. Budi Utama.

Fitriah, Suyanti. 2016. Pengaruh Kualitas Pelayanan terhadap Kepatuhan Wajib Pajak dalam Membayar Pajak Kendaraan Bermotor di Samsat Kota Gorontalo. Skripsi. Universitas Negeri Gorontalo.

Herdiana, Dian. 2020. Pengawasan Kolaboratif dalam Pelaksanaan Kebijakan Bantuan Sosial Terdampak Covid-19. Vol 3. No.2 http://jurnal.univrab.ac.id

Maleong, Lexy J. 200. Metodologi Penelitian Kualitatif. Bandung : PT Remaja Rosdakarya.

Muchlis. 2015. Pengaruh Kualitas Pelayanan Publik terhadap Kepuasan Masyarakat di Kecamatan Wonosari. Skripsi. Universitas Muhamdiyah Gorontalo.

Muhamad, Aji, dan Suarta. 2014. FaktorFaktor yang Berpengaruh terhadap Efektivitas Penyaluran Bantuan Sosial di Bagian Sosial Sekretariat Daerah Kabupaten Kutai Timur. Vol 2. No.1. http://ejournals.unmul.ac.id
Nasir, Novia. 2020. Implementasi Kebijakan Program Keluarga Harapan (PKH) dalam Meningkatkan Kesejahteraan Keluarga di Desa Luhu Kecamatan Telaga Kabupaten Gorontalo. Skripsi. Fakultas Ekonomi. Manajemen. Universitas Negeri Gorontalo.

Sugiyono. 2007. Metode Penelitian Kuantitatif Kualitatif dan R\&D. Bandung: Alfabeta.

-------. 2011. Metode Penelitian Kuantitatif Kualitatif dan R\&D. Bandung: Alfabeta.

-------. 2017. Metode Penelitian Kuantitatif Kualitatif. Bandung: Alfabeta. Sukardi. 2014. Metodologi Penelitian Pendidikan Kompetensi dan Praktiknya. Jakarta: Bumi Aksara.

Tjiptono, Fandy. 2015. Strategi Pemasaran. Yogyakarta: Penerbit ANDI.

Trisnawati, dan Mika Niluh. 2015. Analisa Faktor-Faktor yang Mempengaruhi Wajib Pajak Membayar Pajak Hotel, Pajak Restoran dan Pajak Hiburan di Kota Denpasar Bali. Tesis. Universitas Udayana Denpasar.

Wildan, Dkk. 2020. Pemetaan Permasalahan Penyaluran Bantuan Sosial untuk Penanganan Covid-19 di Indonesia. Vol II. No.1 resi.ariyasa@pknstan.ai.id

Winarta, Agung dan Sumada. 2020. Evaluasi Kebijakan Penyaluran Dana Bantuan Sosial di Pemerintah Kabupaten Gianyar. Vol 5. No.1 http://ejournal.warmadewa.ac.id 